\title{
Angiocardiography and magnetic resonance imaging to assess pulmonary regurgitation in repaired tetralogy of Fallot
}

\author{
Fallot tetralojisi nedeniyle tüm düzeltme ameliyatı uygulanmış hastalarda pulmoner \\ yetmezliğin miktarını belirlemek için anjiyokardiyografi ve manyetik rezonans \\ görüntüleme
}

İlkay Erdoğan, Alpay Çeliker, Tuncay Hazırolan*, Mithat Haliloğlu*, Tevfik Karagöz

From Departments of Pediatric Cardiology and *Radiology, Hacettepe University, Ankara, Turkey

Objective: This study aimed to compare the results of angiocardiography and cardiovascular magnetic resonance imaging in the assessment of pulmonary regurgitation following repair of tetralogy of Fallot.

Methods: We prospectively studied 37 patients with repaired tetralogy of Fallot. After routine examination cardiovascular magnetic resonance imaging (CMR) and cardiac catheterization and angiography were performed. Pulmonary regurgitation (PR) was classified according to the following criteria, using a left lateral angiogram of the main pulmonary artery; insufficiency jet is limited to right ventricular outflow tract (mild); jet reaches the body of right ventricle (moderate); jet fills the apex of the right ventricle (severe).

Results: Pulmonary regurgitation determined by angiocardiography and CMR was severe in $51.4 \%$ and $32.4 \%$, moderate in $27 \%$ and $40.5 \%$, and none or mild in $21.6 \%$ and $27 \%$ of patients respectively. The ability of semi-quantitative estimation of PR determined by cardiac catheterization to distinguish between mild, moderate and severe pulmonary regurgitation was shown to have significant correlation with pulmonary regurgitant fraction obtained by CMR.

Conclusions: Angiography obtained during invasive study can be used for the diagnosis and follow-up of pulmonary regurgitation confidently in patients with repaired tetralogy of Fallot and residual pulmonary regurgitation.

(Anadolu Kardiyol Derg 2010; 10: 353-7)

Key words: Pulmonary valve insufficiency, angiography, cardiac magnetic resonance imaging, tetralogy of Fallot follow-up

ÖZET

Amaç: Bu çalışma pulmoner yetmezliğin miktarının belirlenmesinde anjiyokardiyografi ve kardiyovasküler manyetik rezonans görüntüleme sonuçlarının karşılaştırılması amaçlanarak prospektif olarak planlanmıştır.

Yöntemler: Fallot tetralojisi nedeniyle tüm düzeltme ameliyatı yapılmış 37 hasta çalışmaya dahil edilmiştir. Hastalara rutin muayene sonrası kardiyovasküler manyetik rezonans görüntüleme (CMR) ile kalp kateterizasyonu ve anjiyografi uygulanmıştır. Pulmoner yetmezlik ana pulmoner artere sol yan pozisyonda yapılan anjiyogramla aşağıdaki kriterler doğrultusunda belirlendi: Yetmezlik jeti sağ ventrikül çıkış yolu ile sınırlı ise hafif; sağ ventrikül gövdesine kadar uzanıyorsa orta; sağ ventrikül apeksini dolduruyor ise ağır pulmoner yetmezlik olarak değerlendirilmiştir.

Bulgular: Anjiyokardiyografi ile pulmoner yetmezlik miktarı hastaların \%51.4'ünde ağır, \%27'sinde orta, \%21.6'sında hafif bulunmuştur. Pulmoner yetmezlik miktarı CMR ile ise hastaların \%32.4'ünde ağır, \%40.5'inde orta ve \%27'sinde hafif olarak saptanmıştır. Çalışma sonucunda kalp kateterizasyonu ile saptanan hafif, orta ve ağır pulmoner yetmezliğin miktarlarının manyetik rezonans görüntüleme yöntemi ile elde edilen sonuçlarla yüksek oranda uyumluluk gösterdiği görüldü.

Sonuç: Bu çalışma sonucunda Fallot tetralojisi nedeniyle tüm düzeltme ameliyatı yapılmış hastaların uzun dönem izlemlerinde pulmoner yetmezliğin miktarını belirlemek için girişimsel çalışmalar sırasında uygulanan anjiyografi görüntülerinin güvenle kullanılabileceği gösterilmiştir.

(Anadolu Kardiyol Derg 2010; 10: 353-7)

Anahtar kelimeler: Pulmoner yetmezlik, anjiyografi, manyetik rezonans görüntüleme, Fallot tetralojisi izlemi

Address for Correspondence/Yazışma Adresi: Dr. Alpay Çeliker, Hacettepe University, Department of Pediatric Cardiology, 06100, Sihhiye, Ankara, Turkey Phone: +90 3123051157 Fax: +903123090220 E-mail: aceliker@hacettepe.edu.tr

Accepted/Kabul Tarihi: 30.12 .2009

(C)Telif Hakkı 2010 AVES Yayıncılık Ltd. Sti. - Makale metnine www.anakarder.com web sayfasından ulaşılabilir.

(C) Copyright 2010 by AVES Yayıncıllk Ltd. - Available on-line at www.anakarder.com 


\section{Introduction}

Intracardiac repair of tetralogy of Fallot has been performed for over 40 years with excellent short and long-term results $(1,2)$; however, morbidity and mortality remain a major concern after surgical therapy (3). Pulmonary regurgitation is the most common sequels of surgery (3). Pulmonary regurgitation seems to be well tolerated by children in the early period (4); however, pulmonary regurgitation leads to progressive right ventricular dilatation, dysfunction, exercise intolerance, ventricular tachycardia, and finally, sudden cardiac death (5-7). Pulmonary valve replacement resolves pulmonary regurgitation and improves cardiac hemodynamics, if it is not performed too late (2).

Cardiovascular magnetic resonance imaging can assess ventricular function and volume, and the extent of pulmonary regurgitation and it is the gold standard for determination of amount of pulmonary regurgitation and assessment of right ventricular functions (8). Nevertheless, in most centers evaluation of pulmonary regurgitation is initially performed by Doppler echocardiography on follow-up examinations. Several studies in literature compare results of magnetic resonance imaging and Doppler echocardiography in the assessment of amount of pulmonary regurgitation $(9,10)$. Patients in whom cardiovascular magnetic resonance imaging is performed may have had cardiac catheterization, angiocardiography and electrophysiological studies for a variety of reasons (2). Pulmonary angiograms that are performed during these invasive studies may reveal the severity of pulmonary regurgitation in addition to right ventricular dilatation and outflow tract pathology evaluated by right ventriculography.

There are several studies comparing Doppler echocardiography and radionuclide assays with cardiac magnetic resonance imaging in the assessment of regurgitant fraction (9); however, there is no study that compares cardiac angiography and cardiac magnetic resonance imaging (CMR) in determining the amount of pulmonary regurgitation.

In this study, we estimated pulmonary regurgitation semiquantitatively by pulmonary angiograms and compared the results of the angiograms with the results of cardiovascular magnetic resonance imaging to assess the ability of angiocardiography to assess pulmonary regurgitation in patients after repair of tetralogy of Fallot.

\section{Methods}

We prospectively studied 37 patients with tetralogy of Fallot after surgical repair. Informed consent was obtained from each patient. The study protocol conforms to the ethical guidelines of the 1975 Declaration of Helsinki as reflected in a priori approval by the institution's human research committee. Patients with prominent pulmonary regurgitation on echocardiography or with symptoms such as palpitations and exercise intolerance and or history of surgery at least 10 years prior to the study were included in the study group. Surgical history and follow-up data were obtained from hospital records and clinic visits. Symptoms were noted. Physical examination, 12 lead electrocardiography, echocardiographic examination, Holter monitoring, cardiovascular magnetic resonance imaging and angiography were performed in all patients. An experienced radiologist and experienced pediatric cardiology stuff performed and evaluated CMR and angiocardiograms.

\section{Cardiac catheterization and angiography}

Pressures of ventricles, great arteries and atria were recorded. Biplane right ventricle and pulmonary artery angiocardiograms were obtained. When we encountered residual ventricular septal defect, we collected blood samples for oxymetry. Pulmonary regurgitation was classified by using the following criteria, using a left lateral angiogram when the pigtail catheter was located far inside the main pulmonary artery (Fig. 1);

Grade I (mild): Insufficiency jet is limited to right ventricular outflow tract.

Grade II (moderate): Insufficiency jet reaches the body of the right ventricle.

Grade III (severe): Insufficiency jet fills the apex of the right ventricle.

\section{Cardiovascular magnetic resonance imaging}

Scans were performed using a 1.5 Tesla magnetic resonance imaging system (Philips Intera Achieva; Philips Medical Systems, Best, the Netherlands) system. Patients were scanned

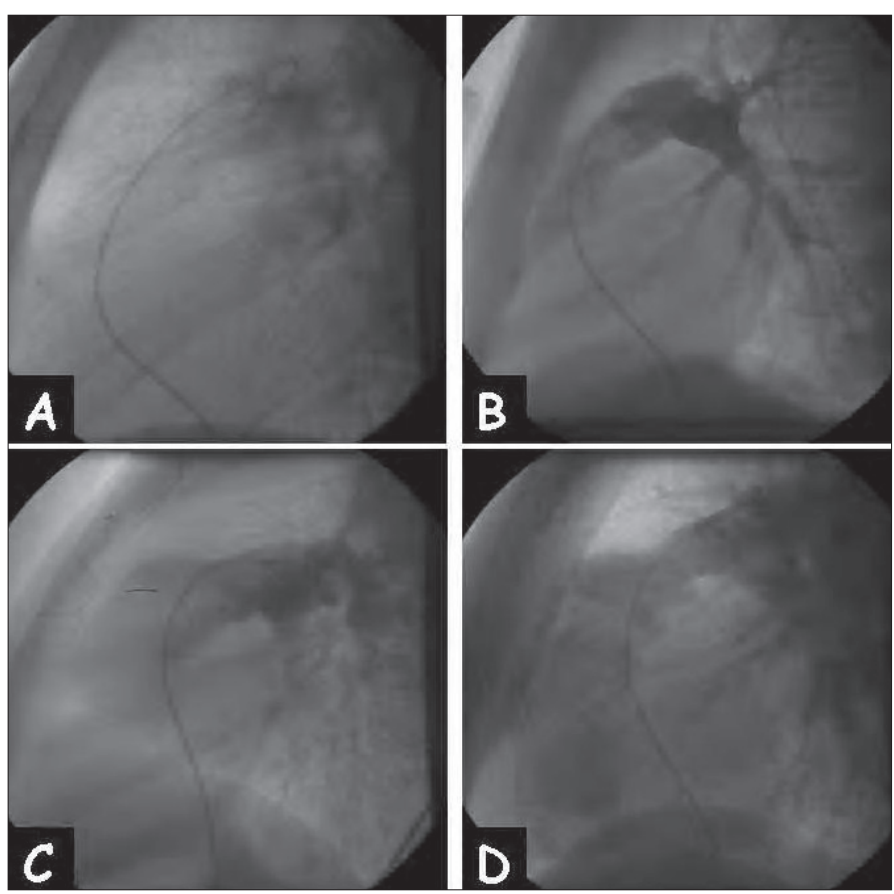

Figure 1. Views of pulmonary angiography obtained by left lateral angulation: (A) No pulmonary regurgitation. (B) Mild pulmonary regurgitation. (C) Moderate pulmonary regurgitation. (D) Severe pulmonary regurgitation 
in the supine position with electrocardiography and breathe follow-up pad. A 5-element phased array cardiac coil was used for signal collection.

Cardiac gated multisegmented cine steady state free precession sequences (balanced turbo field echo) was used to assess the right ventricular function. Cine imaging parameters were as follows: repetition time/time echo, 3.1/1.6 milliseconds; flip angle, 60 degrees; field of view: $320-380 \mathrm{~mm}$; slice thickness, $8 \mathrm{~mm}$; gap, $2 \mathrm{~mm}$. Cine-magnetic resonance provides multiple slices that cover the entire volume of the right ventricle. Each slice is recorded in multiple phases of the cardiac cycle. By manually tracing endocardial contours of the end-diastolic and end-systolic phases of each slice, it is possible to calculate the volume and function of the right ventricle (2).

For assessment of regurgitation fraction phase shift velocity, mapping was performed with a flow-sensitive gradient-echo sequence. Phase-shift velocity mapping parameters were as follows: repetition time/time echo 4.8/2.8 milliseconds; flip angle, 15 degrees; field of view: $320-380 \mathrm{~mm}$; slice thickness, $8 \mathrm{~mm}$. This method allows calculation of flow velocity and flow volume by velocity-dependent phase shift of the moving spins. A perpendicular orientation directly cranial to the pulmonary valve was used to quantify flow volumes. To obtain reliable flow volumes, the tolerated deviation of perpendicular orientation was 15 degrees maximum. Encoded velocity was $200 \mathrm{~cm} / \mathrm{second}$. In the event of aliasing, encoded velocity was increased in increments of $25 \mathrm{~cm} / \mathrm{second}$ up to $300 \mathrm{~cm} / \mathrm{second}$. Pulmonary insufficiency above $40 \%$ was considered severe and was considered moderate if regurgitation fraction of pulmonary insufficiency was between $20 \%$ and $40 \%$ (8). A magnetic resonance imaging-derived right ventricular ejection fraction of $35 \%$ or less was accepted as depressed ejection fraction and $47.2 \%$ or greater was accepted as normal $(1,3)$.

\section{Statistical analysis}

Calculations were performed using the SPSS version 11.5 software (SPSS Inc., Chicago, IL, USA). Values are expressed as means ( \pm standard deviation) or medians (ranges). Pearson's correlation is used to express the relationship between different variables. All groups were compared with all others pair-wise using the Mann-Whitney test and Student's t-test. The distribution of pulmonary regurgitation fractions on CMR among the angiocardiograms categories is depicted using box plot diagrams.

\section{Results}

The study group consisted of 37 patients ( 31 male, 6 female) with surgical correction of tetralogy of Fallot and with a mean age of $17 \pm 8$ years (range 7-47; median 16 years). Surgical repair had been performed at a mean age of $4.3 \pm 3$ years (range 2 months- 12 years; median 4 years). The mean duration of follow-up was $12 \pm 7$ years (range 3-40 years; median 12 years). Previous palliative shunt surgery was performed in six patients. Transannular patch was used in 25 patients, ventricular patch in 10 patients.
Symptomatology was as follows: asymptomatic (14 patients), palpitations (10 patients), syncope and presyncope (seven patients) and fatigue (four patients). Two patients experienced sudden cardiac arrest and were successfully resuscitated (Right ventricle functions ere normal in one of these patients, there was severe PR and right ventricular aneurysm in the other patient. Both of them were asymptomatic until cardiopulmonary arrest). We decided to perform pulmonary valve reconstruction surgery in eleven patients in consideration of their clinical status and results of echocardiography, cardiac magnetic resonance and cardiac catheterization studies.

\section{Cardiac Catheterization and Angiography}

Right ventricular end systolic pressure was $44 \pm 12 \mathrm{mmHg}$ (23$67 \mathrm{mmHg}$ ) and right ventricular end diastolic pressure was $4 \pm 2.5$ $\mathrm{mmHg}(0-10 \mathrm{mmHg})$. Pressure gradient between the main pulmonary artery and right ventricle was greater than $20 \mathrm{mmHg}$ in eleven patients. Pulmonary regurgitation was severe in 19 patients $(51.4 \%)$, moderate in 10 patients $(27 \%)$ and absent or mild in eight patients $(21.6 \%)$ according to previously described criteria. Residual ventricular septal defect was detected in six patients ( $0 p / 0$ s ratio was between 1 and 1.2 in these patients).

\section{Magnetic resonance imaging findings}

The mean pulmonary regurgitant fraction was $31 \pm 21 \%$ (range $0-70$; median $30 \%$ ). Pulmonary regurgitant fraction was $40 \%$ or more in 14 patients $(38 \%)$. The mean right ventricular ejection fraction was $35 \pm 7 \%(25-49$, median $34 \%)$ and it was $35 \%$ or less in 19 patients $(51 \%)$. Right ventricular end- diastolic volume was $96 \pm 32 \mathrm{ml} / \mathrm{m}^{2}\left(33-128\right.$, median $\left.93 \mathrm{ml} / \mathrm{m}^{2}\right)$, right ventricular endsystolic volume was $66 \pm 30 \mathrm{ml} / \mathrm{m}^{2}\left(25-156\right.$, median $\left.58 \mathrm{ml} / \mathrm{m}^{2}\right)$ and right ventricular stroke volume was $33 \pm 12 \mathrm{ml} / \mathrm{m}^{2}(17-64.5$, median $\left.32 \mathrm{ml} / \mathrm{m}^{2}\right)$.

\section{Angiocardiography versus cardiac magnetic resonance imaging}

There was significant correlation between pulmonary regurgitant fraction (PRF) obtained by CMR and pulmonary insufficiency measured by angiocardiogram $(r=0.414, p<0.001$,). The ability of semi-quantitative estimation of pulmonary regurgitation determined by cardiac catheterization to distinguish between mild and moderate grades vs. and moderate and severe grades of pulmonary regurgitation showed a significant correlation with pulmonary regurgitant fraction measured by CMR (Fig. 2). There was no significant correlation between PRF and surgical method regarding the annular patch reconstruction $(r=0.13, p>0.05)$

\section{Discussion}

Pulmonary regurgitation is extremely common in patients after total correction of tetralogy of Fallot and pulmonary regurgitation seems to be well tolerated by children $(1,4)$; however, several recent studies emphasize that pulmonary regurgitation 


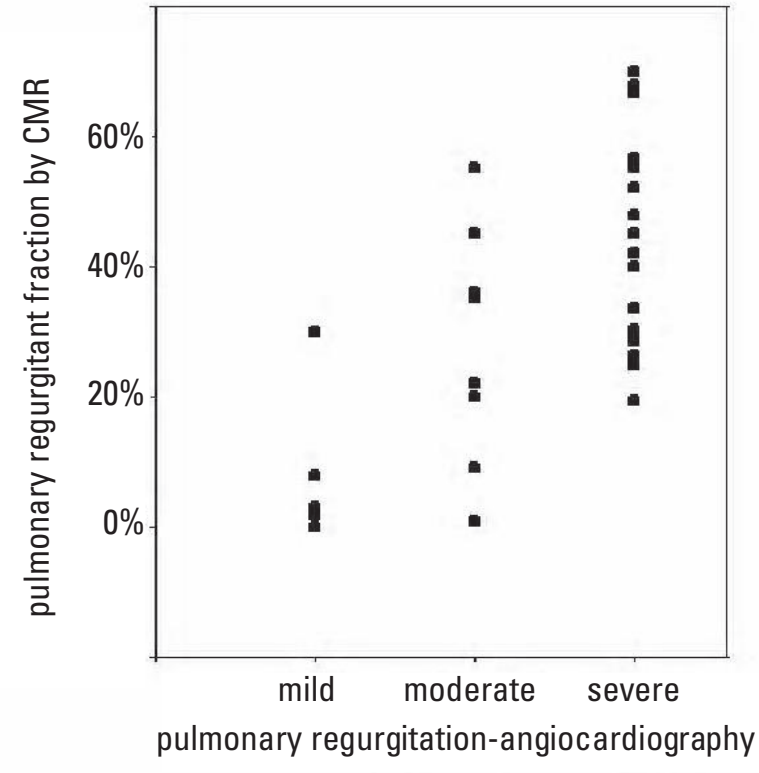

Figure 2. Histogram comparison of the degree of pulmonary insufficiency as determined by cardiovascular magnetic resonance (CMR) flow measurements and angiocardiography in patients with repaired tetralogy of Fallot

leads to progressive right ventricular dilatation and even to dysfunction, exercise intolerance, ventricular tachycardia and finally, sudden cardiac death $(2,5-8)$. Non-invasive and invasive studies give the opportunity for assessment of pulmonary regurgitation and right ventricular function. Bouzas et al. (3) stated that cardiovascular magnetic resonance imaging has become the gold standard for the periodic evaluation and follow-up of patients with pulmonary regurgitation (3). There are several studies comparing Doppler echocardiography and radionuclide assays with cardiac magnetic resonance imaging in the assessment of regurgitant fraction (9); however, this is the first study that compares cardiac angiography and cardiac magnetic resonance imaging in determining the amount of pulmonary regurgitation. In our study there was significant correlation between pulmonary regurgitant fraction (PRF) obtained by CMR and pulmonary insufficiency measured by angiocardiogram $(r=0.414$, $p<0.001)$. The ability of semi-quantitative estimation of pulmonary regurgitation determined by cardiac catheterization to distinguish between mild and moderate grades vs. and moderate and severe grades of pulmonary regurgitation showed a significant correlation with pulmonary regurgitant fraction measured by CMR. There was no significant correlation between PRF and surgical method regarding the annular patch reconstruction. The ability of semi-quantitative estimation of pulmonary regurgitation as assessed by cardiac catheterization to distinguish between mild and moderate grades, and moderate and severe grades of pulmonary regurgitation showed significant correlation with the pulmonary regurgitant fraction obtained by CMR.
This study demonstrated the significance and reliability of the semi-quantitative estimation of pulmonary regurgitation determined by angiocardiography in the assessment of pulmonary insufficiency. Semi-quantitative categories obtained by cardiac angiocardiograms - mild, moderate and severe pulmonary insufficiency were concordant with the amount of pulmonary insufficiency measured by CMR flow. Angiocardiography obtained during an invasive study therefore can be used confidentially in the assessment of the degree of pulmonary regurgitation. In view of these findings, angiocardiography seems to be the best method for evaluation of amount of pulmonary regurgitation in patients with pacemakers and after coil embolization because CMR is limited in these cases.

Cardiac catheterization provides the opportunity to determine the pressures of chambers and great arteries, and pressure gradients, especially in case of residual pulmonary stenosis; however, it is not possible to evaluate the right ventricular function by cardiac catheterization. CMR is the gold standard for the assessment of right ventricular function.

\section{Study Limitations}

Number of patients in the study is not sufficient to make strong conclusion. Amount of pulmonary regurgitation determined by both methods may be compared with the clinical status of patients and biochemical parameters related to heart failure (for example brain natriuretic peptide).

\section{Conclusion}

Pulmonary regurgitation is an important long-term complication of total correction of tetralogy of Fallot. Severity of pulmonary regurgitation can be assessed by cardiac magnetic resonance imaging examination. Our study demonstrates that results of magnetic cardiac magnetic resonance imaging phase-contrast flow measurements show good correlation with semiquantitative measurements obtained by pulmonary artery angiograms obtained during invasive study. Therefore, pulmonary angiography can be used confidently for the diagnosis and follow-up of pulmonary regurgitation.

Conflict of interest: None declared.

\section{References}

1. Harrison DA, Siu SC, Hussain F, MacLoghlin CJ, Webb GD, Harris L. Sustained atrial arrhythmias in adults late after repair of tetralogy of fallot. Am J Cardiol 2001; 87: 584-8.

2. Davlouros PA, Kilner PJ, Hornung TS, Li W, Francis JM, Moon JC, et al. Right ventricular function in adults with repaired tetralogy of Fallot assessed with cardiovascular magnetic resonance imaging: detrimental role of right ventricular outflow aneurysms or akinesia and adverse right-to-left ventricular interaction. J Am Coll Cardiol 2002; 40: 2044-52.

3. Bouzas B, Kilner PJ, Gatzoulis MA. Pulmonary regurgitation: not a benign lesion. Eur Heart J 2005; 26: 433-9. 
4. Wessel HU, Cunningham WJ, Paul MH, Bastanier CK, Muster AJ, Idriss FS. Exercise performance in tetralogy of Fallot after intracardiac repair. J Thorac Cardiovasc Surg 1980; 80: 582-93.

5. Carvalho JS, Shinebourne EA, Busst C, Rigby ML, Redington AN. Exercise capacity after complete repair of tetralogy of Fallot: deleterious effects of residual pulmonary regurgitation. Br Heart J 1992 ; 67: 470-3.

6. Redington AN, Oldershaw PJ, Shinebourne EA, Rigby ML. A new technique for the assessment of pulmonary regurgitation and its application to the assessment of right ventricular function before and after repair of tetralogy of Fallot. Br Heart J 1988; 60: 57-65.

7. Oosterhof T, Mulder BJ, Vliegen HW, De Roos A. Cardiovascular magnetic resonance in the follow-up of patients with corrected tetralogy of Fallot: a review. Am Heart J 2006; 151: 265-72.
8. Harrild DM, Berul Cl, Cecchin F, Geva T, Gauvreau K, Pigula F, et al. Pulmonary valve replacement in tetralogy of Fallot: impact on survival and ventricular tachycardia. Circulation 2009; 119: 445-51.

9. Grothoff M, Spors B, Abdul-Khaliq H, Gutberlet M. Evaluation of postoperative regurgitation after surgical repair of tetralogy of Fallot: comparison between Doppler echocardiography and MR velocity mapping. Pediatr Radiol 2008; 38: 186-91.

10. Li W, Davlouros PA, Kilner PJ, Pennell DJ, Gibson D, Henein MY, et al. Doppler-echocardiographic assessment of pulmonary regurgitation in adults with repaired tetralogy of Fallot: comparison with cardiovascular magnetic resonance imaging. Am Heart J 2004; 147: $165-72$. 